\title{
TEODYCEA W KONTEKŚCIE WSPÓŁCZESNYCH OSIĄGNIĘĆ NAUK BIOLOGICZNYCH
}

\section{WSTĘP}

Słowo teodycea zawarte $\mathrm{w}$ tytule pracy pochodzi $\mathrm{z}$ języka greckiego (theon dikein) i dosłownie oznacza „usprawiedliwienie Boga”. „Pod pojęciem teodycei należy rozumieć obronę najwyższej mądrości Pierwszego Poruszyciela świata przed skargą, jaką wnosi przeciwko tejże rozum wychodząc ze sprzeczności obecnej w świecie. Nazywa się to obroną sprawy Boga"'.

W celu zrozumienia wyjątkowego charakteru chrześcijańskiej doktryny o stworzeniu należy przedstawić poglądy greckich filozofów na

* Dr hab. Tomasz Ilnicki, biolog, nauczyciel akademicki w Instytucie Botaniki Uniwersytetu Jagiellońskiego. Interesuje się ewolucją biologiczną i genetyką w ramach specjalności zawodowej cytogenetyka. Dodatkowe jego zainteresowania obejmują zagadnienia interdyscyplinarne z pogranicza biologii i nauki chrześcijańskiej (tomasz.ilnicki@ interia.eu).

1 I. Kant, Über das Mißlingen aller philosophischen Versuche in der Theodizee, Darmstadt 1971, s. 105. 
temat obecności zła w świecie. Starożytni Grecy uważali, z czym był w stanie się zgodzić św. Tomasz z Akwinu, że materia jest wieczna, ale posiada pewien defekt odpowiedzialny za zło świata. Z takiej materii demiurg mógł utworzyć jedynie niedoskonały świat. $W$ ten sposób starali się uniknąć sprzeczności zawartej w poglądzie o stworzeniu niedoskonałego świata przez „doskonałego” demiurga ${ }^{2}$. Bóstwo to nie mogło być też doskonałe, gdyż niezależnie od niego istniała wieczna materia. Z drugiej strony starożytni, dostrzegając wiele zła w świecie, nie mogli przyjąć koncepcji stworzenia ex nihilo, która ma swoje źródło w 2 Mch 7,28 Starego Testamentu. Według teodycei Jana Szkota Eriugeny z IX wieku ${ }^{3}$ oraz innych chrześcijańskich myślicieli średniowiecznych Bóg, przewidując grzech Adama i Ewy, stwarza świat od początku niedoskonały, jakby „w drodze”4, ze zjawiskami takimi jak śmierć, mutacje i choroby, które są w chrześcijańskim rozumieniu skutkami grzechu pierworodnego (sprawa śmierci biologicznej jest komentowana w dalszej części artykułu). Świadczą o tym słowa z Rz 8,19-23:

Bo stworzenie z upragnieniem oczekuje objawienia się synów Bożych. Stworzenie bowiem zostało poddane marności - nie $\mathrm{z}$ własnej chęci, ale ze względu na Tego, który je poddał - w nadziei, że również i ono zostanie wyzwolone $\mathrm{z}$ niewoli zepsucia, by uczestniczyć $\mathrm{w}$ wolności i chwale dzieci Bożych. Wiemy przecież, że całe stworzenie aż dotąd jęczy i wzdycha w bólach rodzenia. Lecz nie tylko ono, ale i my sami, którzy już posiadamy pierwsze dary Ducha, i my również całą istotą swoją wzdychamy, oczekując "przybrania za synów” - odkupienia naszego ciała ${ }^{5}$.

Według poglądów socjobiologicznych, psychologów ewolucyjnych i ekologów behawioralnych ${ }^{6}$ oraz filozofii Pierre’a Teilharda de Chardina ${ }^{7}$

2 E. McMullin, Ewolucja i stworzenie, Kraków 1993, s. 10.

3 A. Kijewska, Renesans karolinski: Alkuin, Eriugena, w: Przewodnik po filozofii średniowiecznej, red. A. Kijewska, Kraków 2012, s. 97-118; J. S. Eriugena, Periphyseon, Kęty 2009, t. I-III.

${ }^{4}$ Katechizm Kościoła Katolickiego, Poznań 1994, nr 310.

${ }^{5}$ Wszystkie cytaty z Biblii zamieszczone w tekście za: Biblia Tysiąclecia, Poznań 2003.

${ }^{6}$ E. O. Wilson, Konsiliencja. Jedność wiedzy, Poznań 2011, rozdz. 7; J. Holeksa, Rodzina. Między biologia a teologią, Kraków 2015.

7 P. T. de Chardin, Fenomen człowieka, Warszawa 1993. 
obecna natura człowieka jest postrzegana jako produkt ewolucji. P. T. de Chardin uważał, że cierpienie z powodu zła jest niezawinionym przez człowieka "produktem ubocznym” ewolucji, ceną za wolność, a nawet ceną miłości ${ }^{8}$. Oznacza to, że człowiek jest z góry karany cierpieniem. W tym przypadku zachodzi pytanie o wielkość kosztów uzyskanej tą drogą wolności. Autor cytowanej książki, Gisbert Greshake, uważa, że pytanie o pogodzenie dobroci Boga $\mathrm{z}$ cierpieniem jest pytaniem nadal otwartym. Druga kwestia pojawiająca się w związku z poglądami filozofa dotyczy usprawiedliwienia zła moralnego przez przerzucanie winy za zło z człowieka na geny wyselekcjonowane w trakcie ewolucji. Jak zrozumieć w tym podejściu przekroczenie przykazania „nie zabijaj” według „Kazania na Górze" z Mt 5 przez jedynie wybuch gniewu, jeśli stworzenie przeszło tak trudną i wyboistą drogę ewolucyjną do punktu Omega? Czy w takim razie ten wymóg Jezusa nie jest zbyt radykalny? Człowiek zamiast być zgodnie z arystotelesowsko-tomistyczną koncepcją „drabiny jestestw” koroną stworzenia, z perspektywy tylko samej ewolucji biologicznej jest postrzegany przez psychologów ewolucyjnych jako zaledwie jedna z gałęzi „ewolucyjnego drzewa życia”. Socjobiologia natomiast jest tylko pewną nadbudową nad stricte naukowym ewolucjonizmem. Jest ona rozwijana a priori, zanim zostanie udowodniona ukryta teza ewolucjonizmu o materialnym charakterze duszy. Stąd wynika światopoglądowy charakter tej koncepcji.

Przedstawiona w pracy koncepcja o wtórnym i częściowym nabyciu przez człowieka natury zwierzęcej na skutek grzechu pierworodnego tłumaczy inaczej niż socjobiologia czy filozofia P. T. de Chardina przyczyny zła i cierpienia w świecie, przez wzbogacenie od dawna stawianych tez na temat zła moralnego i przyrodniczego o współczesne implikacje pochodzące $z$ biologii.

Główny cel pracy, jakim jest usprawiedliwienie Boga, będzie realizowany $\mathrm{w}$ ramach sformułowanej $\mathrm{w}$ pracy koncepcji teologiczno-biologicznej przez przedstawienie: 1) z jednej strony zjawisk przyrodniczych, będących czynnikami ewolucji biologicznej (śmierć, horyzontalny przepływu genów, mutacje), które wpłynęły na naturę i kondycję fizyczną i psychiczną człowieka oraz w rezultacie na moralny wymiar człowie-

${ }^{8}$ G. Greshake, Dlaczego Bóg pozwala nam cierpieć, Kielce 2008. 
czeństwa; 2) a $\mathrm{z}$ drugiej strony przez wyjaśnienie tego stanu rzeczy na podstawie teologicznych prawd o Bogu i Jego miłosierdziu wyrażonym w podwójnym akcie stwórczym: stworzenia świata i odkupienia człowieka przez śmierć i zmartwychwstanie Jezusa Chrystusa w związku z zawodem, jaki uczynił człowiek swemu Stwórcy, popełniając w ogrodzie Eden grzech pierworodny.

\section{ASPEKT TEOLOGICZNO-FILOZOFICZNY BOŻEGO PLANU ZBAWIENIA}

W świetle słów z Iz 45,7: „Ja czynię światło i stwarzam ciemności, sprawiam pomyślność i stwarzam niedolę. Ja, Pan czynię to wszystko" nie tylko światło, ale też ciemności, jako przejawy zła przyrodniczego, są wykorzystane do zbawienia świata. Zjawiska te, którym towarzyszy cierpienie, są dopustem Bożym i dlatego należy je zaliczyć do dobra o charakterze osobliwym. Oczywiście to nie oznacza bierności ze strony człowieka i braku przeciwdziałania ich negatywnym skutkom przez rozwój techniki i medycyny w celu ich łagodzenia.

Z tego względu obecność w świecie ciemności i niedoli (śmierć, choroby, mutacje, okrucieństwo i bezduszność przyrody) nazwałem skutkami celowymi grzechu pierworodnego. W proponowanej koncepcji rozwojem i doskonaleniem świata kieruje Logos jako forma świata (arystotelizm), wykorzystując w tym celu konsekwencje grzechu. Dlatego można te skutki nazwać celowymi, gdyż są użyte w celu zbawienia człowieka. Celem istnienia i rozwoju organizmu żywego i świata są odpowiednio dusza i Bóg. Analogicznie widzi to Richard Dawkins w relacji między ciałem organizmu a jego genami. Samolubne geny wykorzystują ciało organizmu jako swego rodzaju opakowanie, służące ich rozprzestrzenianiu się, czyli ciało jest dla genów, a nie odwrotnie, geny dla ciała. W tym przypadku geny są odpowiednikiem duszy ${ }^{9}$. Podobnie w arystotelizmie ciało jest dla duszy, a świat dla Boga. W stanie grzechu pierworodnego i odwrócenia się człowieka od Stwórcy Ciało człowieka obarczone tego konsekwencjami jest jednak potrzebne duszy dla jej zbawienia, a ostatecznie wraz z duszą dla jego odnowienia w dniu zmartwychwstania („Wierzę ... w ciała

\footnotetext{
${ }^{9}$ R. Dawkins, Fenotyp rozszerzony, Warszawa 2003.
} 
zmartwychwstanie” - Credo). Logos jako forma świata wyprowadza dla siebie świat $\mathrm{z}$ chaosu ku porządkowi „według swego postanowienia, które przedtem w Nim [Chrystusie] powziął dla dokonania pełni czasów, aby wszystko na nowo zjednoczyć w Chrystusie jako Głowie: to, co w niebiosach, i to, co na ziemi” (Ef 1,9b-10). Według opisu z Rdz 1,2: „Ziemia zaś była bezładem i pustkowiem: ciemność była nad powierzchnią bezmiaru wód, a Duch Boży unosił się nad wodami”. Porządek wyłania się drogą ewolucji. Na początku pojawiły się na ziemi mniej złożone organizmy. Kolejne, wyżej położone warstwy geologiczne zawierają skamieniałości powstałe z coraz bardziej skomplikowanych w budowie organizmów, ale dana grupa organizmów mieści się w swoim przedziale czasowym, w jakim żyła na ziemi. Tak więc działania duszy i Logosu mają swój nadrzędny i doniosły cel, o którym będzie mowa w dalszej części artykułu.

Dokonując recepcji wczesnochrześcijańskich poglądów neoplatońskich, historia rozpoczyna się od osobliwego punktu nieskończoności Bożej Nicości (Damazjos) ${ }^{10}$. Z tego punktu wyłania się jako pierwsza natura, niestworzona i stwarzająca (Bóg Ojciec). Poznając Siebie samą w wiecznym akcie poznawania, charakteryzującym się $\mathrm{w}$ tej fazie dynamizmem stwarzania, rodzi drugą naturę stworzoną i stwarzającą jako Syna Bożego ze swym wiecznym Ciałem-Kościołem reprezentującym świat jako trzecią naturę, która jest stworzona i niestwarzająca. Ze zjednoczenia Syna i Ojca pochodzi Osoba Ducha Świętego, stanowiąc wspólnie czwartą naturę niestworzoną i niestwarzającą w postaci Trójcy Świętej i będąc ostatecznie kresem i celem wszystkich dążeń (odniesienie do Trójcy jest moją własną adaptacją poglądów Jana Szkota Eriugeny). Tym końcowym zdarzeniem jest samoprzyczyna Boga osobowego, w którym Bóg staje się tym, kim Jest dzięki samopoznaniu Boga wyrażonym w dynamizmie rodzenia i stwarzania: „Duch przenika wszystko, nawet głębokości Boga samego” (1 Kor 2,10); mimo że w ostatecznej postaci Bytu nie ma ruchu - T.I. (Trójca Święta). W związku z aktem samopoznania Boga, prowadzącym do osiągnięcia samoświadomości, ponosi On wielki koszt, którym jest samoponiżenie się przez swoje uczestnictwo w bycie stworzonym. Rozwój osobowy Jezusa, prowadzący do Jego samoświadomości jako równego

10 A. Sparty, Dzieje filozofii starożytności chrześcijańskiej i średniowiecza, Poznań 1992, t. 4, s. 27. 
Bogu Ojcu od betlejemskiego żłóbka do wieku dorosłego aż do punktu kulminacyjnego, jakim jest Pascha krzyża, jest według mnie swoistą rekapitulacją wydarzeń prowadzących do samoświadomości (samopoznania) Boga. Pojęcie rozwoju Boga jest jedynie pewną analogią zaczerpniętą ze znanego nam świata istniejącego w czasie, które nie może być adekwatne do tajemnic Bożych.

W odpowiedzi na teologiczne pytanie Gottfrieda Wilhelma Leibniza: „Dlaczego istnieje raczej coś niż nic?” należałoby stwierdzić na podstawie tych rozważań, że istnienie „czegoś” wynika z aktu samopoznawczego Boga, w którym Bóg poznaje własne Dobro. Natomiast „nic”, będące $\mathrm{w}$ ontologii starożytnej nieznanym pojęciem filozoficznym, jest niebytem, brakiem Dobra, czyli złem moralnym (św. Augustyn). W Bogu nie ma braków, „W Nim bowiem mieszka cała Pełnia” (Kol 2,9), a więc nie ma w Nim zła moralnego: „Nowina, którą usłyszeliśmy od Niego i którą wam głosimy, jest taka: Bóg jest światłością, a nie ma w Nim żadnej ciemności" (1 J 1,5) ${ }^{11}$.

Z niewysłowionej Bożej Nicości (Absolutu) wyłania się jako jedyna przyczyna dla Siebie samej Trójjednia: Ojciec, Syn i Duch Święty w akcie samoobjawienia zrealizowanym w podwójnym akcie stwórczym, tj. powołania do istnienia i odkupienia świata, dzięki któremu Bóg poznaje własne Dobro stanowiące Jego istotę. W związku z tym aktem, prowadzącym do osiągnięcia Jego samoświadomości, ponosi On wielki koszt, którym jest samoofiarowanie się przez uczestnictwo w bycie stworzonym dla jego zbawienia. Ojciec Niebieski, rodząc Syna, równocześnie stwarza Mu (przez stworzenie i zbawienie ludzkości z grzechu) Jego Ciało-Kościół. „Ojcze [...] cokolwiek mi dałeś, pochodzi od Ciebie [...]. Wszystko bowiem moje jest Twoje, a Twoje jest moje, i w nich zostałem otoczony chwałą" (J 17,7.10). Oznacza to, że przez Ojca został On otoczony chwałą, otrzymując w darze Mistyczne Ciało, które jest Jego koroną, za sprawą powierzonej Mu przez Ojca szczytnej misji zbawienia świata: „Przeto przychodząc na świat mówi: Ofiary ani daru nie chciałeś, ale mi utworzyłeś Ciało" (Hbr 10,5). Chwałą Boga, czyli Jego postacią, jest Kościół jako Mistyczne Ciało Chrystusa.

Miłosierny Stwórca nie chciał, aby pierwotnie nieśmiertelny czło-

${ }^{11}$ Wyraźnie należy tutaj odróżnić zło przyrodnicze od zła moralnego. 
wiek pozostał na wieczność obciążony winą i skutkami grzechu. Dlatego dzięki istnieniu śmierci i złożonej ofierze na krzyżu przez Jezusa Chrystusa stał się on nowym stworzeniem: „Jeżeli więc ktoś pozostaje w Chrystusie, jest nowym stworzeniem. To, co dawne, minęło, a oto wszystko stało się nowe” (2 Kor 5,17), „A jeżeli mieszka w was Duch Tego, który Jezusa wskrzesił z martwych, to Ten, co wskrzesił Chrystusa » Jezusa « z martwych, przywróci do życia wasze śmiertelne ciała mocą mieszkającego w was swego Ducha” (Rz 8,11). Śmierć została pochłonięta przez wieczne życie zmartwychwstałego Chrystusa, który w darze przekazuje to życie swemu stworzeniu: „Ukazana zaś została ona teraz przez pojawienie się naszego Zbawiciela, Chrystusa Jezusa, który przezwyciężył śmierć, a na życie i nieśmiertelność rzucił światło przez Ewangelię" (2 Tm 1,10). Śmierć jest więc głównym skutkiem celowym grzechu pierworodnego wykorzystanym $\mathrm{w}$ akcie samopoznawczym Boga, wyrażonym poza samym stworzeniem ex nihilo, w odkupieniu człowieka przez śmierć Syna Bożego na krzyżu, czyli w podwójnym akcie stwórczym.

\section{ASPEKT PRZYRODNICZY BOŻEGO PLANU ZBAWIENIA}

Omawiając biologiczne skutki grzechu pierworodnego, należy wymienić w pierwszej kolejności śmierć biologiczną. Jej ślady zostały odciśnięte w pokładach skamieniałości organizmów żyjących w odległych epokach geologicznych. Bez niej w krótkim czasie ziemia zostałaby zapełniona przez rozmnażające się w przyroście geometrycznym organizmy, a ziemskie zasoby pokarmowe szybko by uległy wyczerpaniu. Paradoksalnie śmierć jest koniecznym warunkiem istnienia życia na ziemi, gdyż przyczynia się do eliminowania organizmów słabiej przystosowanych w konkurencji o ograniczone zasoby bytowe środowiska naturalnego, a więc ma ona charakter pozytywny.

Warto przy tej okazji omówić podstawowe przyczyny umierania organizmów. Jedną z nich jest stopniowe skracanie się końców chromosomów, tzw. telomerów, w każdej rundzie replikacyjnej DNA podczas fazy S cyklu komórkowego, kiedy zachodzi prowadzona przez enzym polimerazę DNA synteza DNA. Na skutek tego, po wielu podziałach komórkowych zwanych mitozą, komórka traci zdolność dzielenia się. 
Wraz z wiekiem wzrasta liczba takich niedzielących się już komórek, które w końcu umierają, co skutkuje deficytem zdrowych komórek w organizmie. Jedynie komórki rozrodcze są chronione przed skracaniem się chromosomów dzięki obecnemu w nich mechanizmowi naprawczemu z udziałem enzymu telomerazy, który potrafi uzupełnić brakujący odcinek nowej nici kwasu nukleinowego. Brak takiego mechanizmu naprawczego w linii komórkowej generatywnej (płciowej) doprowadziłby do tego, że z pokolenia na pokolenie coraz krótsze chromosomy byłyby przekazywane potomstwu i w efekcie organizmy z liniowym DNA przestałyby istnieć na ziemi. Tylko prokarionty z zamkniętym, kolistym DNA nie mają tego problemu, ponieważ ich cząsteczka DNA nie posiada wolnych końców i replikowana jest przez polimerazę DNA w całości. Do skutków grzechu, ale tym razem negatywnych, zaliczam również losowo pojawiające się mutacje genetyczne będące głównym czynnikiem mikroewolucji. Powodują one $\mathrm{z}$ reguły niekorzystne dla organizmu letalne zmiany $\mathrm{w}$ genotypie. Inną przyczyną śmierci są wolne rodniki o dużej sile destrukcyjnej, które uszkadzają struktury komórkowe.

Zgodnie z przekazem K. Rodzaju człowiek do czasu popełnienia pierwszego grzechu przebywał w środowisku wyjątkowym, nazywanym ogrodem Eden, pozbawionym zagrożeń ze strony drapieżników i drobnoustrojów chorobotwórczych. Zgodnie ze słowami mędrca Syracha $(18,3)$ : „Przyodział ich w moc podobną do swojej i uczynił ich na swój obraz”, byli oni mocni, zdrowi i doskonali. Na czym więc polegało pogorszenie sytuacji bytowej i kondycji człowieka wraz ze zmianą środowiska po wygnaniu z Edenu? Można je tłumaczyć wzrostem zagrożenia ze strony dzikich zwierząt, o czym wyraźnie wspomina Stary Testament. Pojawiło się dodatkowo zagrożenie, nieznane w Edenie, ze strony pasożytów i drobnoustrojów chorobotwórczych, w tym wirusów. Można więc wysnuć pewną teorię, która pozwala przynajmniej częściowo odpowiedzieć na powyższe pytanie. Według ostatnich doniesień naukowych wirusy są „uciekinierami” z komórki eukariontów, posiadających jądra komórkowe, które zaczęły funkcjonować jako wolne kwasy nukleinowe. Ich budowa DNA/RNA jest bardzo podobna do ruchomych elementów genomu (transpozonów), co dowodzi ich pochodzenia ${ }^{12}$. Stosunkowo niedawno

${ }_{12}$ S. M. Rogalska, A. Kalinka, M. Achrem, R. Słomińska-Walkowiak, L. Skuza, 
odkryto takie chorobotwórcze nagie nici kwasu nukleinowego, które nazywają się flavowirusami. Następnie niektóre z tych wolnych nici kwasów nukleinowych nabyły geny kodujące białka strukturalne kapsydów. Takim przykładem jest wirus HIV ze złożoną otoczką białkową pozwalającą mu osiąść na zewnętrznej powierzchni błony komórkowej białych ciałek krwi, aby wprowadzić do ich wnętrza własny kwas nukleinowy, a następnie namnożyć się tam, wykorzystując do tego celu aparat genetyczny gospodarza. W kwasie nukleinowym wirusów mogą występować też onkogeny, które po włączeniu do DNA komórek gospodarza przyczyniają się do rozwoju raka. Obecnie produkuje się szczepionki przeciwko tym wirusom. Trudno sobie wyobrazić, żeby Stwórca stworzył bezpośrednio wirusy, których nie zalicza się do organizmów żywych! Musiały pojawić się na ziemi wtórnie, drogą ewolucji, w czasie kiedy już istniały organizmy żywe, bez których nie mogą one samodzielnie funkcjonować. Wirusy nazywane bakteriofagami, czyli wirusami bakteryjnymi, infekują też bakterie. Można przypuszczać, że niektóre początkowo dobroczynne bakterie stały się zjadliwe (transgeniczne) na skutek przypadkowo pozostawianych fragmentów kwasu nukleinowego wirusa w ich kolistych cząsteczkach DNA, podobnie jak to jest w przypadku onkogenów. Obcy DNA może wywołać zmianę ekspresji genów gospodarza albo stać się nowym genem. W ten sposób pojawiło się nowe źródło chorób człowieka, którym są bakterie chorobotwórcze. Infekcje drobnoustrojów wywołujące choroby są kolejnym negatywnym skutkiem celowym grzechu pierworodnego (oczywiście z punktu widzenia życia doczesnego).

Wirusy pozostawiają, ale też zabierają ze sobą geny z DNA gospodarza przez niewłaściwe nacięcia nici DNA podczas uwalniania się z genomu i następnie przekazują je niekiedy organizmom należącym do obcych gatunków. W ten sposób te same geny mogą występować w genomach daleko spokrewnionych organizmów, które nie krzyżują się ze sobą (na przykład ten sam element genetyczny u niektórych kotów i małp Starego Świata). To zjawisko, związane nie tylko z wirusami, ale także z plazmidami bakterii, nazywa się horyzontalnym transferem lub

E. Filip, Genetyczne elementy ruchome u roślin i innych organizmów, „Kosmos” 53 (2004), s. $325-342$. 
przepływem genów ${ }^{13}$, w odróżnieniu od pionowego przekazywania genów, odbywającego się w rozmnażaniu płciowym poprzez gamety. Tę inwazyjną właściwość kwasu nukleinowego wykorzystuje się w terapii genowej przez wprowadzanie brakującego genu do organizmu człowieka. W przypadku roślin przeprowadza się transfer genów do komórek roślin poprzez plazmidy za pomocą bakterii Agrobacterium ${ }^{14}$. Te przykłady sztucznego, „horyzontalnego" wprowadzania genów do organizmów potwierdzają, że podobne zjawiska mogą zachodzić na dużą skalę w naturze. Obecne $\mathrm{w}$ genomie tzw. ruchome elementy zwane transpozonami i retrotranspozonami, z których najwyraźniej pochodzi wirusowy kwas nukleinowy, co wyraża się w ich bardzo podobnym składzie nukleotydowym DNA, mają zdolność gromadzenia się $\mathrm{w}$ dużej liczbie kopii $\mathrm{w}$ genomach zwierząt i roślin. Te elementy genomu, z powodu braku w nich genów służących komórce, nazywa się w literaturze naukowej samolubnym (selfish) i niekodującym DNA, który w nadmiarze kopii może zagrażać gatunkowi w skali globalnej przez wywoływanie zbyt licznych mutacji i szkodliwy nadmiar ilości DNA ${ }^{15}$. W przeciwieństwie do wirusowego DNA przekazywany jest on $\mathrm{z}$ pokolenia na pokolenie wraz z gametami drogą płciową i dlatego z czasem gromadzi się w dużej ilości w komórkach ${ }^{16}$.

Wymienione powyżej fakty świadczą o globalnym genetycznym „zepsuciu” przyrody ożywionej, co odpowiada cytowanym na początku artykułu słowom św. Pawła z Listu do Rzymian o poddaniu marności stworzenia przez Stwórcę (8,19-23). W efekcie przekazywania z genomu na genom fragmentów DNA pomiędzy różnymi gatunkami zapewne następowała stopniowa infiltracja materiału genetycznego przez obce DNA. W przypadku człowieka spowodowało to negatywne zmiany jego

13 Tamże; S. L Salzberg, O. White, J. Peterson, J. A. Eisen, Microbial genes in the human genome: Lateral transfer or gene loss?, „Science” 292 (2001), s. 1903-1906; H. Ochman, J. G. Lawrence, E. A. Groisman, Lateral gene transfer and the nature of bacterial innovation, „Nature” 405 (2000), s. 299-304.

${ }^{14}$ J. S. Heslop-Harrison, T. Schwarzacher, Organisation of the plant genome in chromosomes, „The Plant Journal” 66 (2011), s. 18-33.

${ }^{15}$ M. Olszewska, T. Sakowicz, Ewolucja rozmiarów genomów jądrowych u roślin okrytozalążkowych, „Postępy Biologii Komórki” 33 (2006) 4, s. 737-751.

${ }^{16}$ S. M. Rogalska, J. Małuszyńska, M. Olszewska, Podstawy cytogenetyki roślin, Warszawa 2012, s. 44. 
biologii przez zmianę Adamowego dziedzictwa genetycznego. Człowiek według przedstawianej teorii nabył wtórną, hybrydyczną naturę z częściowo przeprogramowanym aparatem genetycznym, odbiegającą od tej, jaką posiadali pierwsi ludzie Adam i Ewa. Konsekwencje tych zmian obejmują budowę ciała, fizjologię i mentalność człowieka. Zmiany mentalne człowieka przejawiają się w samodestrukcji i agresji (w wywoływaniu walk i wojen, niezdrowej konkurencji i zachowaniach aspołecznych).

\section{UZASADNIENIE STAWIANYCH TEZ PRACY}

Przedstawiona teoria globalnego występowania w świecie skutków grzechu pierworodnego, poruszająca również problem ciała człowieka, nie jest moim zdaniem sprzeczna $z$ dogmatem o Niepokalanym Poczęciu Najświętszej Maryi Panny sformułowanym przez Piusa IX 8 grudnia $1854 \mathrm{roku}^{17}$. Papież pozostawia pewne niedomówienia, pozwalające na dopasowanie dogmatu do faktów odkrytych przez naukę (na przykład dzieworództwo u zwierząt, przyczyny śmierci biologicznej itp.). Rozważając problem skażenia genetycznego natury, nie można więc pominąć sprawy charakteru ciała Maryi i Pana Jezusa. Według Rz 8,3 ciało Jezusa było podobne do naszego: „Co bowiem było niemożliwe dla Prawa, ponieważ ciało czyniło je bezsilnym, tego dokonał Bóg. On to zesłał Syna swego w ciele podobnym do ciała grzesznego i dla usunięcia grzechu wydał w tym ciele wyrok potępiający grzech". Według Monsabrégo ciało, jakie przyjął od Matki Bożej, było „...biedne, nieszczęsne...” ${ }^{18}$. Maryja odziedziczyła śmiertelne ciało po swoich rodzicach z rodu Dawida, św. św. Joachima i Anny, ale na pewno bez wad genetycznych (pkt 4 Dodatku)! Można to tłumaczyć w Jej przypadku „szczęśliwym układem genów” za sprawą opatrzności Bożej. Św. Franciszek w „Pieśni słonecznej” chwali Boga „przez siostrę naszą Śmierć cielesną, której żaden człowiek żywy uniknąć nie może". Śmiertelność ciała Matki Bożej nie podważa więc dogmatu o jej Niepokalanym Poczęciu.

17 G. Lohfink, L. Weimer, Maryja - nie bez Izraela. Nowe spojrzenie na nauke o Niepokalanym Poczęciu, Poznań 2010, s. 369.

18 J. L. Monsabré, Rozważania różańcowe, Lwów 1930, s. 12. 
W ramach przedstawionej koncepcji słowa św. Pawła, że grzech mieszka w ciele i o skażonej jego naturze, należy, moim zdaniem, powiązać z obecnością obcych genów w genomie człowieka.

Jeżeli zaś czynię to, czego nie chcę, już nie ja to czynię, ale grzech, który we mnie mieszka. A zatem stwierdzam w sobie to prawo, że gdy chcę czynić dobro, narzuca mi się zło. Albowiem wewnętrzny człowiek we mnie ma upodobanie zgodne $\mathrm{z}$ Prawem Bożym. W członkach zaś moich spostrzegam prawo inne, które toczy walkę z prawem mojego umysłu i podbija mnie $\mathrm{w}$ niewolę pod prawo grzechu mieszkającego $\mathrm{w}$ moich członkach. Nieszczęsny ja człowiek! Któż mnie wyzwoli z ciała, co wiedzie ku tej śmierci? Dzięki niech będą Bogu przez Jezusa Chrystusa, Pana naszego! Tak więc umysłem służę Prawu Bożemu, ciałem zaś - prawu grzechu. (Rz 7,20-25)

Nie oznacza to usprawiedliwiania czynionego zła, św. Paweł daje nam bowiem do zrozumienia $\mathrm{w}$ przedostatnim zdaniu tego fragmentu, że $\mathrm{w}$ domyśle łaska może przezwyciężać genetyczne uwarunkowania mentalnych problemów człowieka, co jest potwierdzone przez Apostoła w 2 Kor 12,9: „lecz (Pan) mi powiedział: Wystarczy ci mojej łaski. Moc bowiem w słabości się doskonali. Najchętniej więc będę się chlubił z moich słabości, aby zamieszkała we mnie moc Chrystusa”. Wina człowieka ochrzczonego polega więc nie na posiadaniu niedoskonałego genotypu, który według mnie należy traktować jako nieusuwalny przez chrzest "grzech, który we mnie mieszka”, będącym w moim rozumieniu „zarzewiem grzechu", ale na odrzuceniu uniewinniającej łaski chrztu, która ma moc przeciwdziałania złym skłonnościom, wynikającym, zgodnie z przedstawioną koncepcją, ze zmienionego genotypu.

W tym właśnie wyraża się znaczenie ofiary Jezusa Chrystusa, że uwalnia ona nas z jarzma zmienionych genotypów, skłaniających do grzechu dzięki ożywieniu naszego ciała mocą Ducha, który przyczynił się do zmartwychwstania Jezusa Chrystusa, co samo w sobie gwarantuje jej skuteczność (Rz 8,11 - cytat w tekście). Natomiast słowa z Iz 53,4-5 przedstawiają to w inny sposób: „Lecz On się obarczył naszym cierpieniem, On dźwigał nasze boleści, a myśmy Go za skazańca uznali, chłostanego przez Boga i zdeptanego. Lecz On był przebity za nasze grzechy, zdruzgotany za nasze winy. Spadła Nań chłosta zbawienna dla nas, a w Jego 
ranach jest nasze zdrowie”. Nie jest to więc niezawinione przez człowieka, wspomniane we wstępie pracy cierpienie w ramach ewolucyjnego procesu (P. T. de Chardin), ale niezawinione i dobrowolne cierpienie Boga-Człowieka z powodu obarczonego winą stworzenia, która to boleść jest dla nas łaską „chłosty zbawiennej”. Dzięki niej można być wyzwolonym z ciała śmierci ku życiu według Ducha. Nie jest to też cierpienie przypadkowe i bezsensowne, jak sugeruje naturalistyczne spojrzenie na świat.

$\mathrm{Z}$ przedstawionych $\mathrm{w}$ artykule analiz, ujętych częściowo według neoplatońskiej wizji świata wynika, że ta sprzeczność, którą starożytni Grecy widzieli między charakterem świata a doskonałością Stwórcy, jest tylko pozorna, ponieważ zjawiska towarzyszące ewolucji, jak choroby, cierpienie, śmierć, bezduszność przyrody, będące wyrazem niedoskonałości materii, są potrzebne Bogu w Jego samoprzyczynie zrealizowanej w Odwiecznym Planie Zbawienia obciążonego winą stworzenia, jęczącego i wzdychającego w bólach rodzenia i oczekującego odkupienia ciała z zepsucia.

W myśl przedstawionej koncepcji teologiczno-przyrodniczej pracy, świat jest rozumiany jako warunkowo konieczny, a nie tylko przygodny, tzn. z jednej strony jako przygodny mógłby być inny pod względem struktury i mechanizmów funkcjonowania (życie mogłoby być oparte na krzeme, a nie na węglu), ale nadal jednak zależny byłby w istnieniu od Stwórcy, natomiast z drugiej strony jest konieczny dla samoprzyczyny Boga. „Jesteś tysiąc razy bardziej potrzebny Bogu, niż On tobie” (kazanie nt. Łk 2,42 mistrza Eckharta ${ }^{19}$ w Jego stawaniu się tym, kim jest On od zawsze, Trójcą. Jego imię brzmi: Jestem, Który Jestem (Wj 3,14). Nie jest to sprzeczność, gdyż wariant świata mógłby być zupełnie inny, ale świat jako taki musi istnieć z powodu pragnienia Stwórcy, aby stać się tym, kim Jest, czyli Trójjedynym. Bez świata i nas Jezus by nie miał swojego Ciała, które jest Jego koroną chwały. $Z$ tej koncepcji wynika również to, że świat, który stanowi jedność z Bogiem, jest Jego wrażeniem (odmiana panenteizmu $\mathrm{z}$ interwencjonizmem Boga ${ }^{20}$ : „Bo w nim żyjemy, poruszamy się i jesteśmy” (Dz 17,28). Panenteizm został przychylnie wskazany

19 L. Kołakowski, Horror metaphysicus, Kraków 2012, s. 111.

${ }^{20}$ J. Figas-Skrzypulec, Drogi myśli od nauk przyrodniczych do teologii. Zapośredniczenia metafizyczne i epistemologiczne, w: Teologia nauki, red. J. Mączka i P. Urbańczyk, Kraków 2015, s. 173-202 (tutaj: s. 194). 
przez Sobór Watykański I i jest pozornie podobny do panteizmu!

Teoria ta jest tylko pewnym przybliżeniem do niezgłębionych tajemnic Boga, do których poznawania jesteśmy jednak przeznaczeni dzięki nieskończonej hojności Stwórcy: „Już was nie nazywam sługami, bo sługa nie wie, co czyni pan jego, ale nazwałem was przyjaciółmi, albowiem oznajmiłem wam wszystko, co usłyszałem od Ojca mego" (J 15,15). Na pewno Pan Bóg oznajmił wszystko co jest konieczne człowiekowi do zbawienia.

W pracy tej wyraźnie jest położony akcent na rolę i znaczenie obciążonego genetycznie ciała człowieka, które ma negatywny wpływ na duszę, w tym na psychikę. Sam rozum, którego nie posiadają zwierzęta ${ }^{21}$, pozostaje jednak nieskażony (KKK), ale z powodu jego słabości nie może przezwyciężyć w dużym stopniu tych obciążeń natury i dlatego potrzebna jest łaska Boża ${ }^{22}$. „Nieuwzględnianie tego, że człowiek ma naturę zranioną, skłonną do zła, jest powodem wielkich błędów w dziedzinie wychowania, polityki i działalności społecznej”23. W odróżnieniu od wąskich materialistyczno-ewolucyjnych poglądów na pochodzenie natury człowieka utracona wysoka pozycja człowieka $\mathrm{w}$ arystotelesowsko-tomistycznej hierarchii bytów wyraża się we wtórnym nabyciu przez niego podobieństwa do zwierząt (Koh 3,18-19), co spowodowało zamazanie w nim prawdziwego obrazu Stwórcy $(\operatorname{Rdz} 1,27)$ i cierpienie z tym związane. Pozostaje jednak nadzieja wyrażona w słowach z Ap 21,4: „I otrze z ich oczu wszelką łzę, a śmierci już odtąd nie będzie. Ani żałoby, ni krzyku, ni trudu już nie będzie, bo pierwsze rzeczy przeminęły”. Nadrzędnym więc celem duszy rozumnej i Boga jako formy świata jest zbawienie człowieka wraz z jego ciałem (zmartwychwstanie) i samopoznanie Boga.

\section{DODATEK}

1) Bóg wyprowadza ze zła dobro, ale nie ma to charakteru przyczynowo-skutkowego, jak w koncepcji P. T. de Chardina, związanego z jakimś procesem przyrodniczym. Odbywa się to poprzez karę Bożą, która jest „zbawienną chłostą” (Biblia).

\footnotetext{
${ }^{21} 1$ Tes 5,23.

22 Thomas à Kempis, O naśladowaniu Chrystusa, Lublin 1986, III, 54,17.

${ }^{23}$ Jan Paweł II, Centesimus annus, Warszawa 2007, nr 25.
} 
2) Usprawiedliwienie zła moralnego, bo tak mnie natura stworzyła w procesie ewolucji, jest kiepskim tłumaczeniem siebie, ponieważ jest to, po pierwsze, błąd naturalistyczny. Już empirysta Hume zauważył, że nie można wyprowadzać moralności z samej natury przyrodniczej. Moralność jest nadrzędna wobec niej i wynika z wiecznych i wrodzonych praw naturalnych. Po drugie, jest to samousprawiedliwienie $\mathrm{w}$ przeciwieństwie do usprawiedliwienia przez odkupieńczą ofiarę Pana Jezusa.

3) Zło moralne nie pochodzi z elementarnych cząstek natury, które są same w sobie dobre ( $\mathrm{Rdz} 1$ ), ale według mojej koncepcji wynika ze złego funkcjonowania niematerialnego kodu genetycznego, co można tłumaczyć skutkiem grzechu pierworodnego (grzech mieszkający w ciele, jak się wyraził św. Paweł, to według mnie wadliwie funkcjonujący niematerialny kod genetyczny w zmienionym na skutek grzechu pierworodnego DNA genomie człowieka, choć sam kod pozostaje prawidłowy). Przyjmując, że zło to brak dobra (św. Augustyn), wadliwe działanie kodu jest tym właśnie brakiem. Sam kod genetyczny można natomiast utożsamić z prawem naturalnym wszczepionym w duszę wegetatywną, zmysłową i rozumną (arystotelizm). Zgodnie z zamysłem Stwórcy współdziała on z materią i jest odpowiednikiem greckiego demiurga.

4) Zdecydowanie odcinam się od twierdzenia neoplatonizmu, że pierwiastek boski nie może się połączyć z domniemaną według niego złą materią, raczej wadliwą, a nie złą. Jezus przyjął przecież ciało podobne do naszego! W wyniku jednak grzechu pierworodnego doszło do skażenia natury na skutek horyzontalnego przepływu genów pomiędzy odległymi od siebie w pokrewieństwie gatunkami i hybrydyzacji międzygatunkowej, co spowodowało, że ten odpowiednik greckiego demiurga, którym jest w tym przypadku niematerialny kod genetyczny, współdziała nieprawidłowo ze zmienioną materią. W ten sposób kod genetyczny został uwikłany w wadliwą materię ciała i nie działa właściwie, choć sam pozostaje nienaruszony, ponieważ jest wieczny.

5) To skażenie ciała jest według mnie tzw. zarzewiem grzechu, będącym konsekwencją grzechu pierworodnego, i przejawia się jako obciążenie genetyczne. Nie wyklucza to natomiast obecności jakiejś 
postaci tego negatywnego zjawiska także w niematerialnej duszy człowieka (KKK 310), ale na pewno nieobecnego w duszy Maryi na skutek Jej uprzedzającego odkupienia i Niepokalanego Poczęcia. Natomiast to skażenie w ograniczonym stopniu było obecne tylko w samym Jej ciele. Adam i Ewa w zasadzie musieli ponieść jakieś konsekwencje swojego grzechu przez obecność jego negatywnych skutków w ich duszach, w sferze na przykład uczuć. Czyli u Adama i Ewy, ponieważ ten grzech miał miejsce po ich narodzeniu, „zarzewie grzechu” było obecne tylko w duszy, natomiast u Maryi tylko w ciele, a nie w duszy. Natomiast u reszty z nas wywiera ono piętno w ciele i w duszy.

6) $\mathrm{W}$ moim rozumieniu śmierć cielesna sama $\mathrm{w}$ sobie, jako skutek grzechu, jest czymś dobrym, choć nie bardzo dobrym. W przeciwieństwie do niej choroby, mutacje są negatywnymi zjawiskami (zło przyrodnicze). Nieśmiertelność jest ostatecznym przeznaczeniem człowieka.

7) Duch (prawo naturalne, kod genetyczny) poprzedza materię, a nie pochodzi z materii, jak to jest w koncepcji P. T. de Chardina.

8) Nauka chrześcijańska powołuje się na prawo naturalne, jako będące podstawą etyki i agatologii. Prawo to opowiada się za dobrem i posiada znaczenie uniwersalne, o czym świadczy sformułowana w 1948 roku Powszechna Deklaracja Praw Człowieka.

9) Racjonalność tego prawa wyrazić można w logice, gdy zapyta się człowieka czyniącego zło: czy wybór zła jest w jego mniemaniu dobrym wyborem? Jeśli odpowie, że tak: to jest dobry wybór, to tym samym zaprzeczy sobie, bo wybrał w jego rozumieniu zło. Nie można bowiem nazywać dobrym wyborem wyboru czegoś złego, bo jest to wewnętrznie sprzeczne. Jeśli natomiast odpowie, że to jest zły wybór zła, to zrozumie wtedy, że dokonał rzeczy bezsensownej, wbrew logice, czyli wbrew naturze stworzonej i wiecznemu prawu naturalnemu (T.I.). Tak więc logika opowiada się za dobrem i dobrym wyborem.

10) Drugi argument: jeśli Bóg istnieje, to musi być dobry, gdyż zły Bóg nie pozwoliłby na istnienie żadnego dobra, a jego istnieniu nie sposób zaprzeczyć (T.I.). 
11) Przedstawiona $w$ artykule natura, $w$ tym natura człowieka, pierwotnie dobra, stworzona na obraz i podobieństwo Boga, ulega przez grzech skażeniu. Oznacza to, że musimy wziąć pod uwagę, że nie wszystko, co dzieje się w przyrodzie i czym jest biologicznie obciążony człowiek, jest dla niego właściwe i może być traktowane jako wskazówka w postępowaniu moralnym. Mimo tego zła przyrodniczego prawo naturalne zachowuje swoją aktualność i stanowi podstawę praw pozytywnych, regulujących stosunki międzyludzkie, jak przykładowo w Powszechnej Deklaracji.

Streszczenie. Istnieją różne koncepcje o charakterze światopoglądowym odnoszące się do problemu natury człowieka. Do takich należy socjobiologia, która przypisuje agresywne i egoistyczne zachowania uwarunkowaniom genetycznym powstałym w procesie ewolucji (tzw. walka o byt). W chrześcijańskiej natomiast perspektywie Bóg stwarza pierwotnie dobrą naturę człowieka, która jednak została skażona przez grzech pierworodny. Bez czynników ewolucji, takich jak śmierć, choroby i mutacje potrzebne w Bożym Planie Zbawienia, człowiek nie mógłby być zbawiony. Bowiem śmierć na krzyżu Jezusa Chrystusa była konieczna do zbawienia ludzi, aby ich uczynić wolnymi. Bóg, aby się objawić Sobie samemu, że jest samym Dobrem, wkracza w świat w celu samoofiarowania się dla jego zbawienia. Podobne poglądy, usprawiedliwiające Boga (teodycea) były rozpowszechnione $\mathrm{w}$ wiekach średnich, $\mathrm{m}$.in. rozwijane $\mathrm{w}$ dziewiątym wieku $\mathrm{w}$ teologii Jana Szkota Eriugeny (panenteizm).

Słowa kluczowe: Boży Plan Zbawienia; ewolucja; grzech pierworodny; teodycea.

Abstract. Theodicy in the Context of the Contemporary Achievements of the Biosciences. There are various conceptions expressing views on the nature of man. For example, sociobiology ascribes human behaviours like aggression and egoism to genetic conditionings formed in the process of evolution (the so-called struggle for existence). In turn, in Christian perspective God created initially perfect nature of man, which was flawed by original sin. Without the factors of evolution like death, mutations, illnesses needed in the Divine Plan of Redemption there would be no salvation for man. The death through the cross of Jesus Christ was needed to redeem the people and set them free. In order to reveal Himself to Himself as the Good, God enters the world in order to sacrifice Himself for its salvation. Similar views on theodicy were popular in the Middle Ages, developed, for example, in the ninth century by the theology of John Scotus Eriugena (panentheism).

Key words: Divine Plan of Redemption; evolution; original sin; theodicy. 


\section{BIBLIOGRAFIA}

Chardin P. T. de, Fenomen człowieka, PAX, Warszawa 1993.

Dawkins R., Fenotyp rozszerzony, Prószyński i S-ka, Warszawa 2003.

Figas-Skrzypulec J., Drogi myśli od nauk przyrodniczych do teologii. Zapośredniczenia metafizyczne i epistemologiczne, w: Teologia nauki, red. J. Mączka i P. Urbańczyk, Kraków 2015, s. 173-202.

Greshake G., Dlaczego Bóg pozwala nam cierpieć, Kielce 2008.

Heslop-Harrison J. S., Schwarzacher T., Organisation of the plant genome in chromosomes, „The Plant Journal” 66 (2011), s. 18-33.

Holeksa J., Rodzina. Między biologią a teologią, Kraków 2015.

Jan Paweł II, Centesimus annus, Warszawa 2007.

Jan Szkot Eriugena, Periphyseon, Kęty 2009, t. 1-3.

Kant I., Über das Mißlingen aller philosophischen Versuche in der Theodizee, Darmstadt 1971, s. 105.

Katechizm Kościoła Katolickiego, Poznań 1994.

Kijewska A., Renesans karoliński: Alkuin, Eriugena, w: Przewodnik po filozofii średniowiecznej, red. A. Kijewska, Kraków 2012, s. 97-118.

Kołakowski L., Horror metaphysicus, Kraków 2012, s. 111.

Lohfink G., Weimer L., Maryja - nie bez Izraela. Nowe spojrzenie na naukę o Niepokalanym Poczęciu, Poznań 2010, s. 369.

McMullin E., Ewolucja i stworzenie, Kraków 1993, s. 10.

Monsabré J. L., Rozważania różańcowe, Lwów 1930, s. 12.

Ochman H., Lawrence J. G., Groisman E. A., Lateral gene transfer and the nature of bacterial innovation, „Nature” 405 (2000), s. 299-304.

Olszewska M., Sakowicz T., Ewolucja rozmiarów genomów jądrowych u roślin okrytozalążkowych, „Postępy Biologii Komórki” 33 (2006) 4, s. 737-751.

Rogalska S. M., Kalinka A., Achrem M., Słomińska-Walkowiak R., Skuza L., Filip E., Genetyczne elementy ruchome u roślin i innych organizmów, „Kosmos” 53 (2004), s. $325-342$.

Rogalska S. M., Małuszyńska J., Olszewska M., Podstawy cytogenetyki roślin, Warszawa 2012, s. 44.

Salzberg S. L., White O., Peterson J., Eisen J. A., Microbial genes in the human genome: Lateral transfer or gene loss?, „Science” 292 (2001), s. 1903-1906.

Sparty A., Dzieje filozofii starożytności chrześcijańskiej i średniowiecza, Poznań 1992, t. 4 , s. 27.

Tomasz à Kempis, O naśladowaniu Chrystusa, Lublin 1986, III, 54,17.

Wilson E. O., Konsiliencja. Jedność wiedzy, Poznań 2011, rozdz. 7. 